

\section{The Together Project: Holi in Jodhpur, India}

\section{Johanna Patton}

Keywords: Holi, Jodhpur, Traditional Festival, India, Asia, Hinduism, Festival of Color, Humanity, Documentary Photography

\section{Abstract}

The Together Project is a series of photo essays inspiring us to see humankind in a different light by honoring our cultural differences as well as the understanding that we're all cut from the same cloth; we're members of humankind. The Together Project is here to inspire you to learn about others and to ignite a sense of curiosity and compassion towards those who live in different cultures from our own.

In this photo essay, Johanna shares her experience in Jodhpur, India celebrating the Holi festival. She shares her experience, the reason Holi is celebrated, as well as the health benefits of the festival. 
JOSHA

Journal of Science, Humanities and Arts

\section{The Festival of Color}

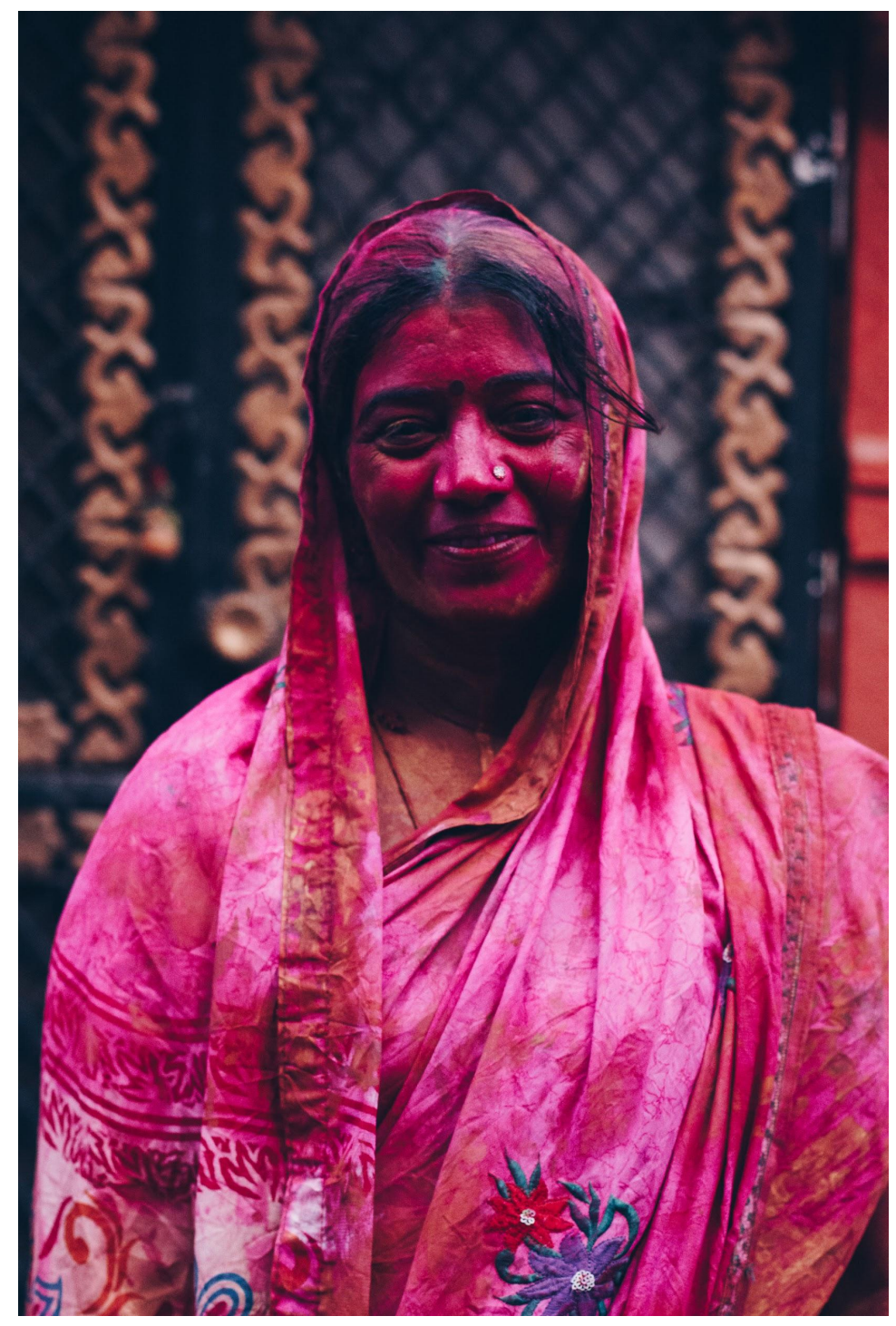

Holi is an ancient Hindu festival otherwise known as the festival of colors. It is a day where music blasts through the streets - where you feel the bass of the stereo playing Indian music buzzing through your bones. It is chaos and joy and laughter and fun. The Holi festival signifies the triumph of good over evil. I wouldn't be able to think of a way to celebrate such a beautiful message even if I tried.

It doesn't matter who you are or where you come from, strangers will come up to you happily saying, "Happy Holi!" and rub colored powder on your face. It's a day where it feels like everyone on the street is a big family. It doesn't matter whether you're man or woman, the color of your skin, how old you are, if you're rich or pooreveryone is fair game to get colored with gulal (also called Abir depending on where you come from). 


\section{JOSHA}

Journal of Science, Humanities and Arts

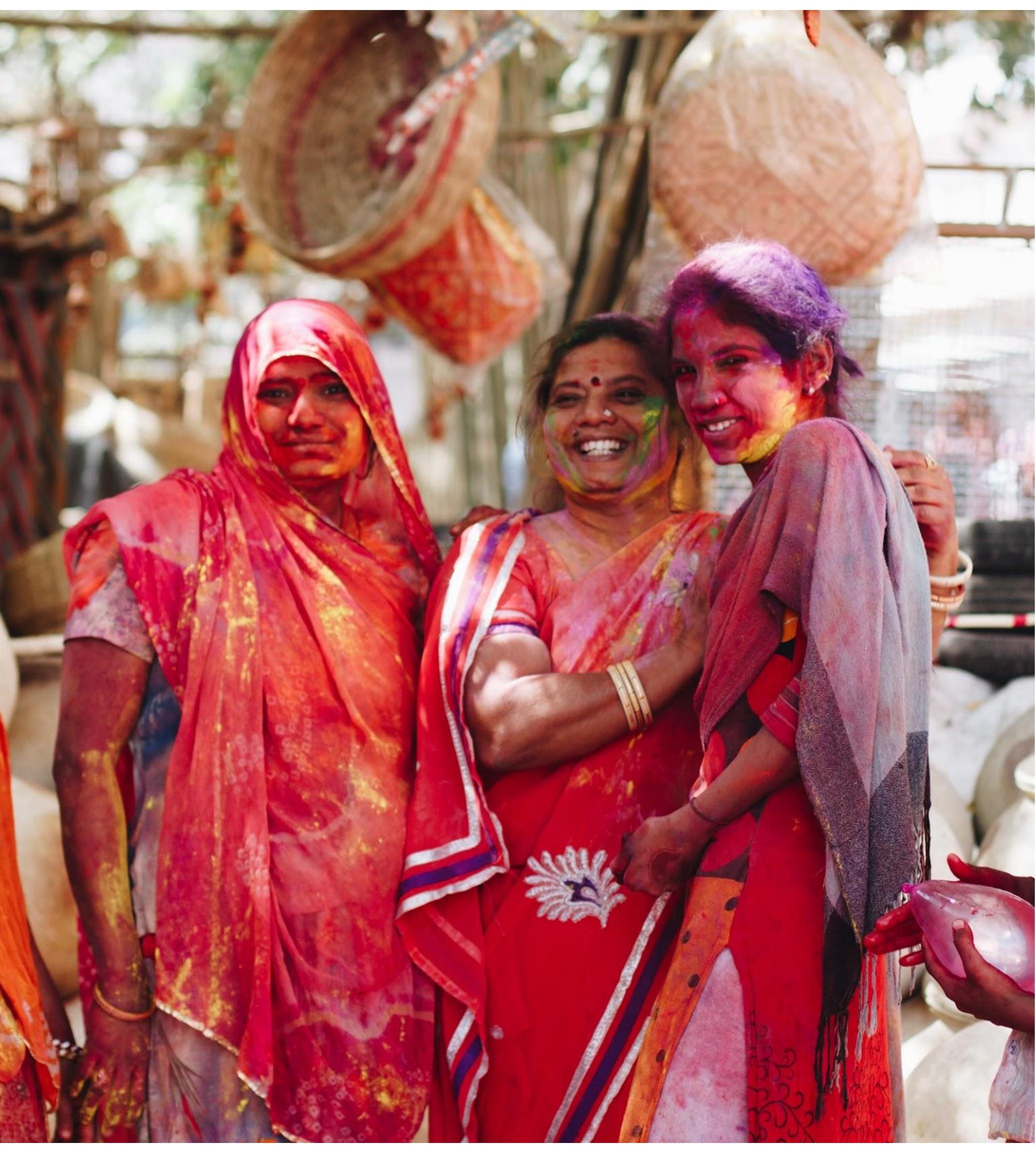


The streets become a free-for-all dance party and groups of people bring drums and other instruments all around the city to play music in and outside of temples, parks, streets, and buildings. Children peak their heads from rooftops with buckets of water waiting for the next passerby to soak. Color is thrown into the air and lands on ancient walls, cows, motorbikes, and anything else on the streets. It brings me back to the same spirit and excitement most of us experience as a child-curious, excited, dancing around without a care in the world. There's a feeling in the air that makes you realize how interconnected we all are and that no one is really a stranger.

Holi originated in India and has spread over different regions of Asia and the west. Although most people recognize Holi as "the festival of colors" and immediately have an idea of what that may look like, the festival actually begins the night before the famous day of color. The festival commences with an event called Holika Dahan which pays tribute to the story that started Holi in the first place.

There are different variations of the story depending on who you ask, although it goes a little bit like this: Once upon a time there was a king and a prince. The king, Hiranyakashipu, was powerful and mighty. He even had special powers that made him close-to-invincible. He thought everyone should worship him, and was filled with so much power he either killed or punished those who disobeyed him. Needless to say how much it infuriated the king when his own son, Prahlad, worshiped Lord Vishnu instead. The king tried to kill the young prince in a variety of ways, but they ultimately were not successful, so he called for the help of his sister, Holika.

He then made the prince sit with Holika in a fire. She was, however, given a special fire-proof blanket but it fell off Holika and landed on top of the young prince instead. As a result, Prahlad's aunt was killed. This is why Holi is commenced with Holika Dahan the day before colors. It's celebrated with a large bonfire. 


\section{JOSHA}

Journal of Science, Humanities and Arts

Volume 8, Issue 4
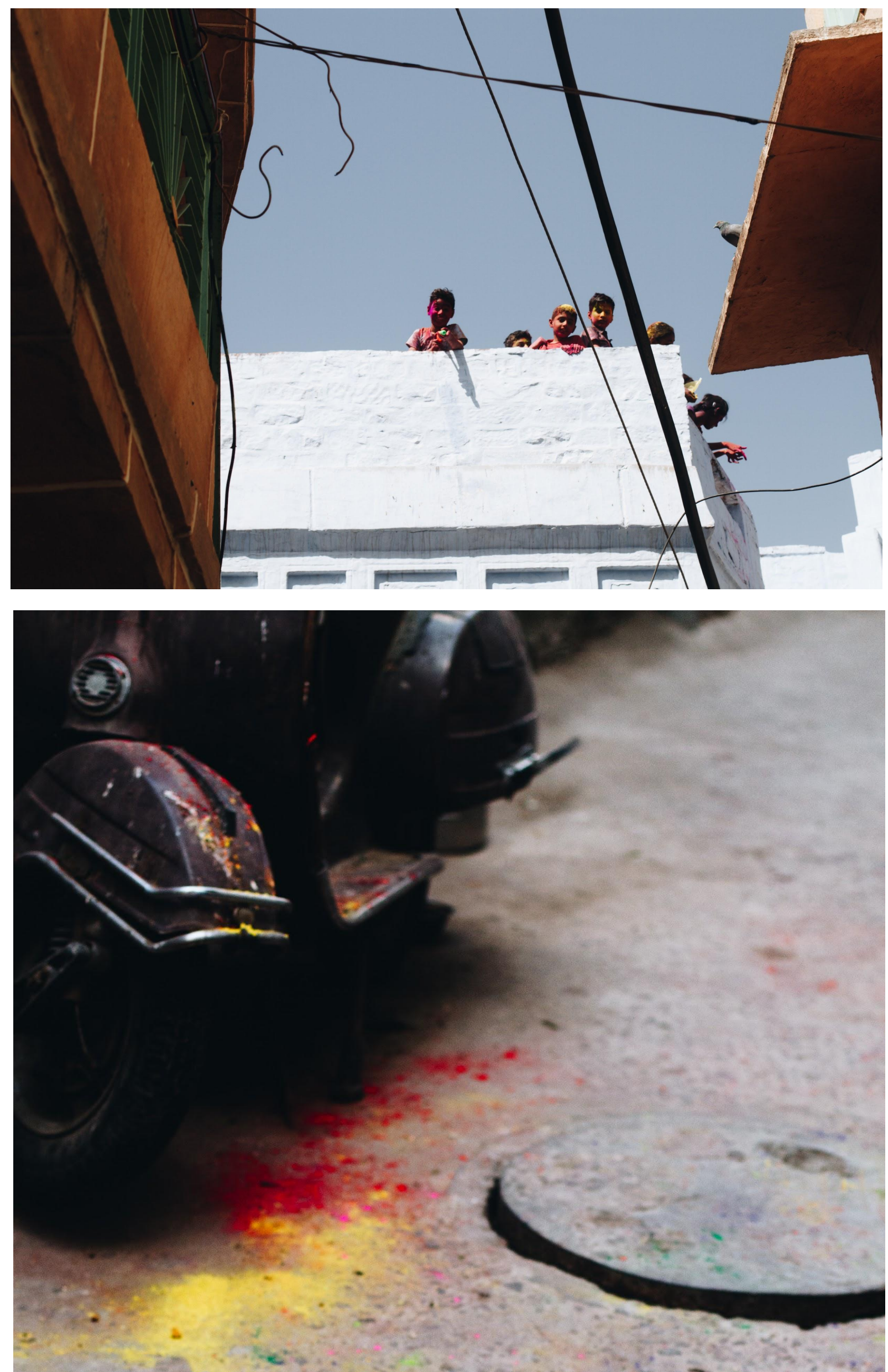


\section{JOSHA}

Journal of Science, Humanities and Arts

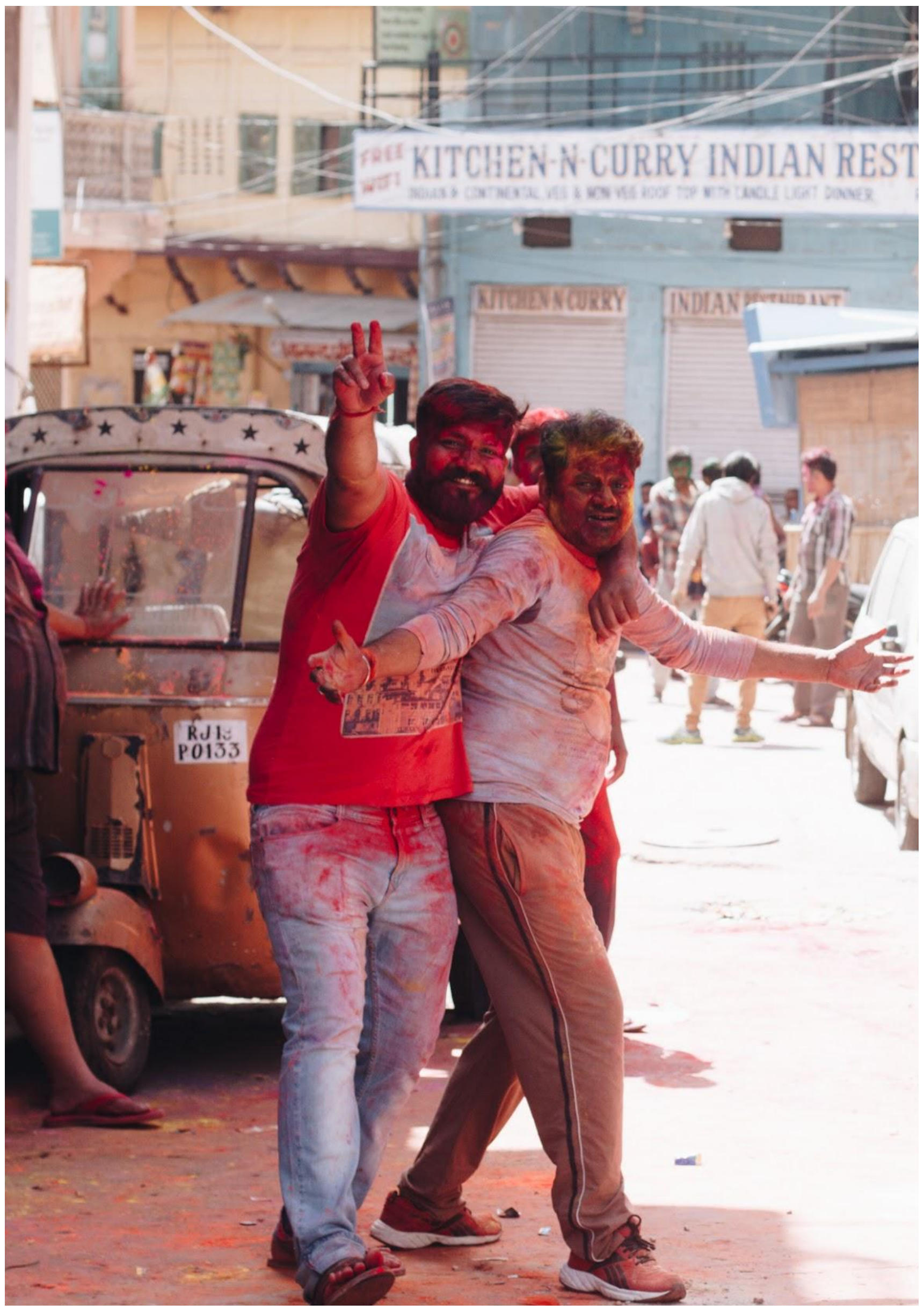


As I learned more about Holi, I realized this celebration is deeply rooted in the ayurvedic health practices, too. Vishakha Moghe writes in her article The Significance of Holika Dahan,

"Holi is largely a North-Indian festival announcing the arrival of spring and more or less falls in the month of March every year. Come spring and we have an array of infections and ailments affecting the body and mind, the reason being a sudden increase in the bacteria that eagerly await wet conditions. The rising heat saps the body of its fluids, leaving it in peril and low on immunity. Amazingly, the ancient societies had their own ways of combating these adverse conditions.

On the day of Holi, as part of the rituals, people get together in large numbers and light fire. They perform "Parikrama" or move around the fire. The heat of the fire helps the body to get rid of the accumulated Kapha, thus preventing diseases that could be caused by the liquefied Kapha. People indulge in heavy activities like shouting slogans and walking briskly around the fire, all of which lead to the digestion of the increased phlegm; thereby rejuvenating the body and mind. Offerings of grains like wheat and barley are made to the Holi bonfire.

The most interesting aspect of this festival is the playful throwing of natural colored medicinal powders all over the streets and over each other. The powders are traditionally prepared from Ayurvedic herbs like Neem... All these powders have a Kapha-reducing property and the power to detox the skin or to help the skin get rid of its toxins...."

Not only is this celebration joy-based, but it actually helps your health too. I'll never forget this day where I was so openly welcomed to dance with strangers to dance, sing, and play. I relived a joy I hadn't felt since I was a child. It can teach us so much about welcoming one another with open arms, of letting go of the things that no longer serve us, and can teach us to start our days with a dance party and to welcome more color into our world. 


\section{JOSHA}

Journal of Science, Humanities and Arts

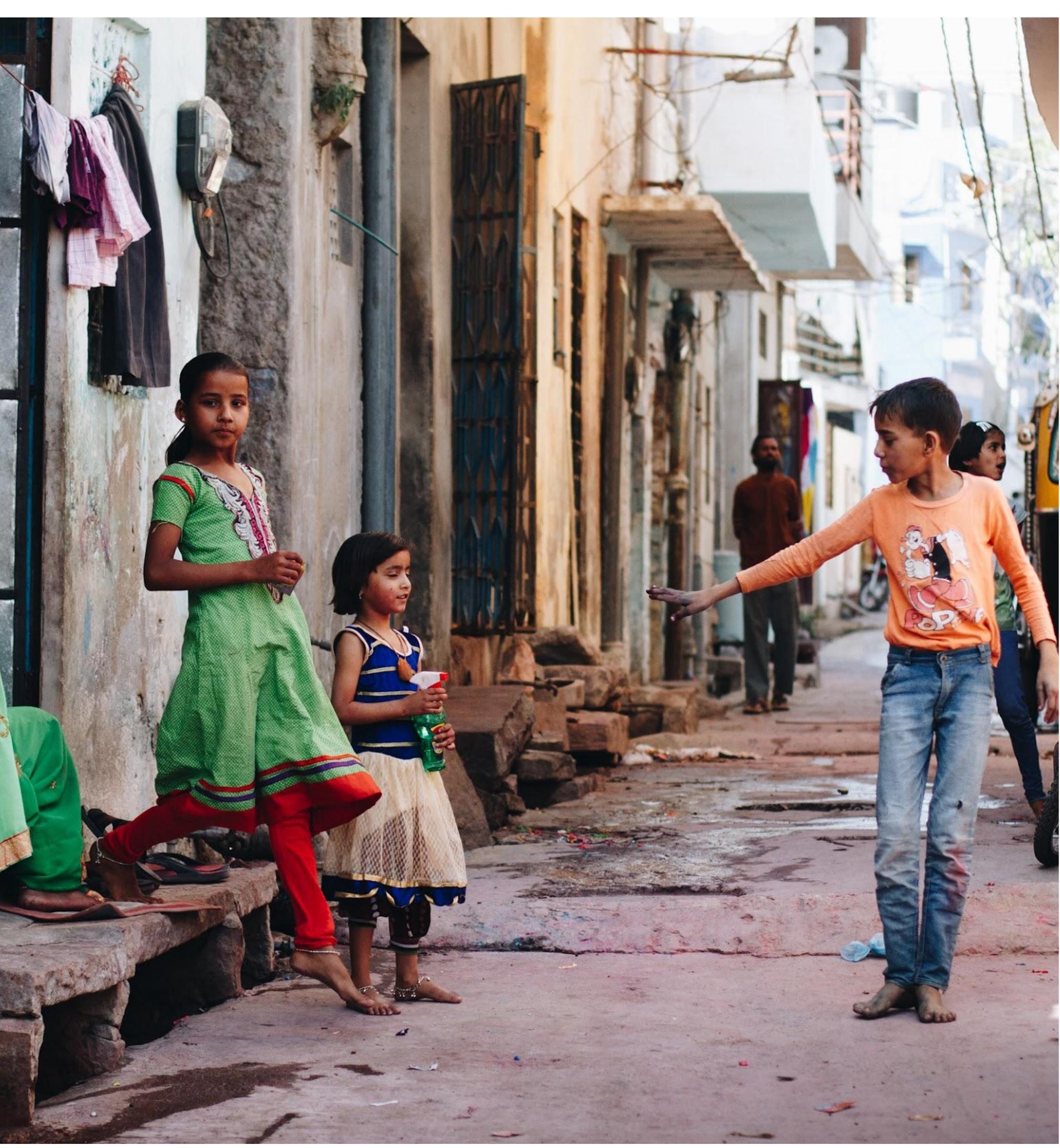




\section{JOSHA}

Journal of Science, Humanities and Arts

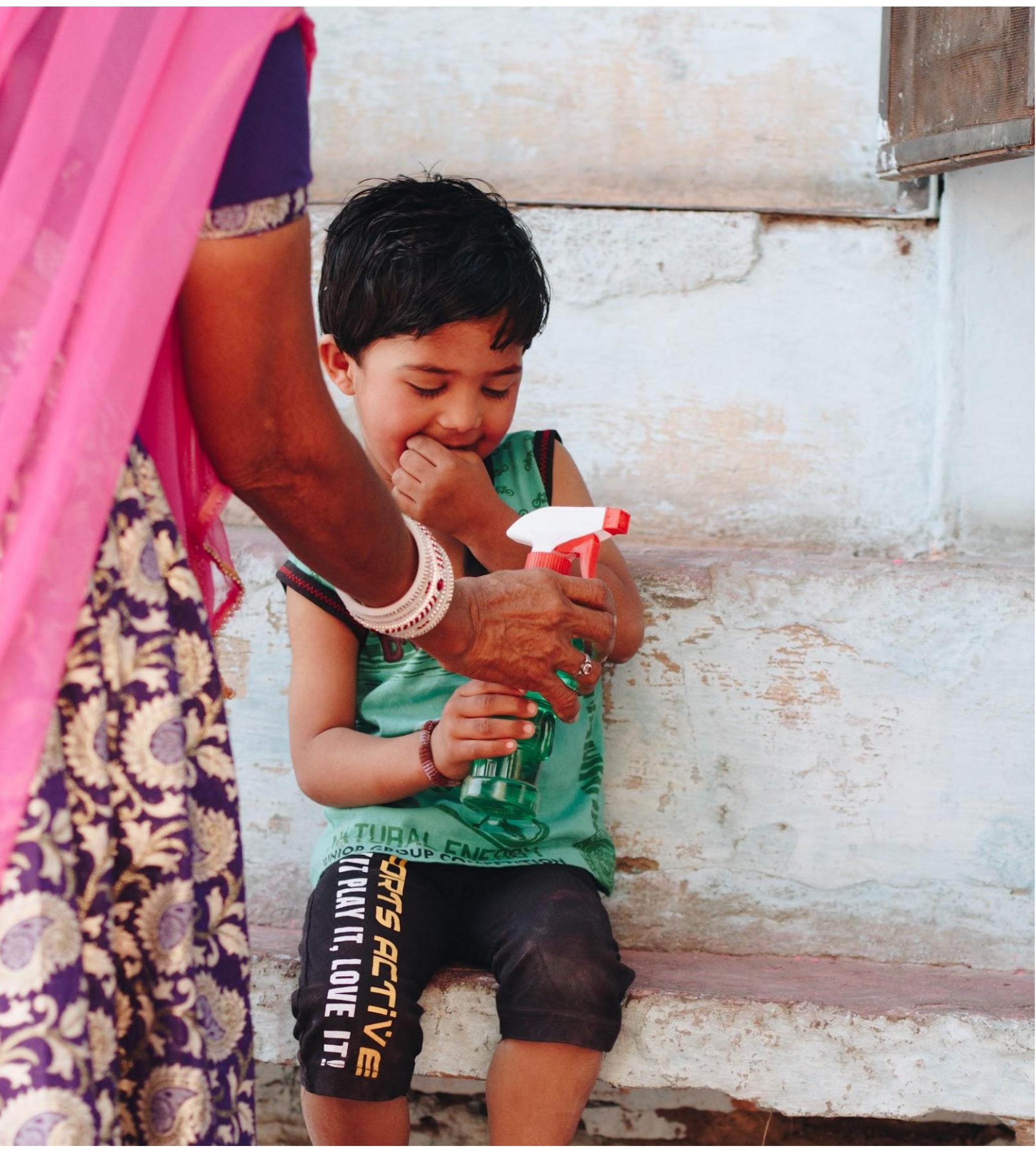




\section{JOSHA}

Journal of Science, Humanities and Arts
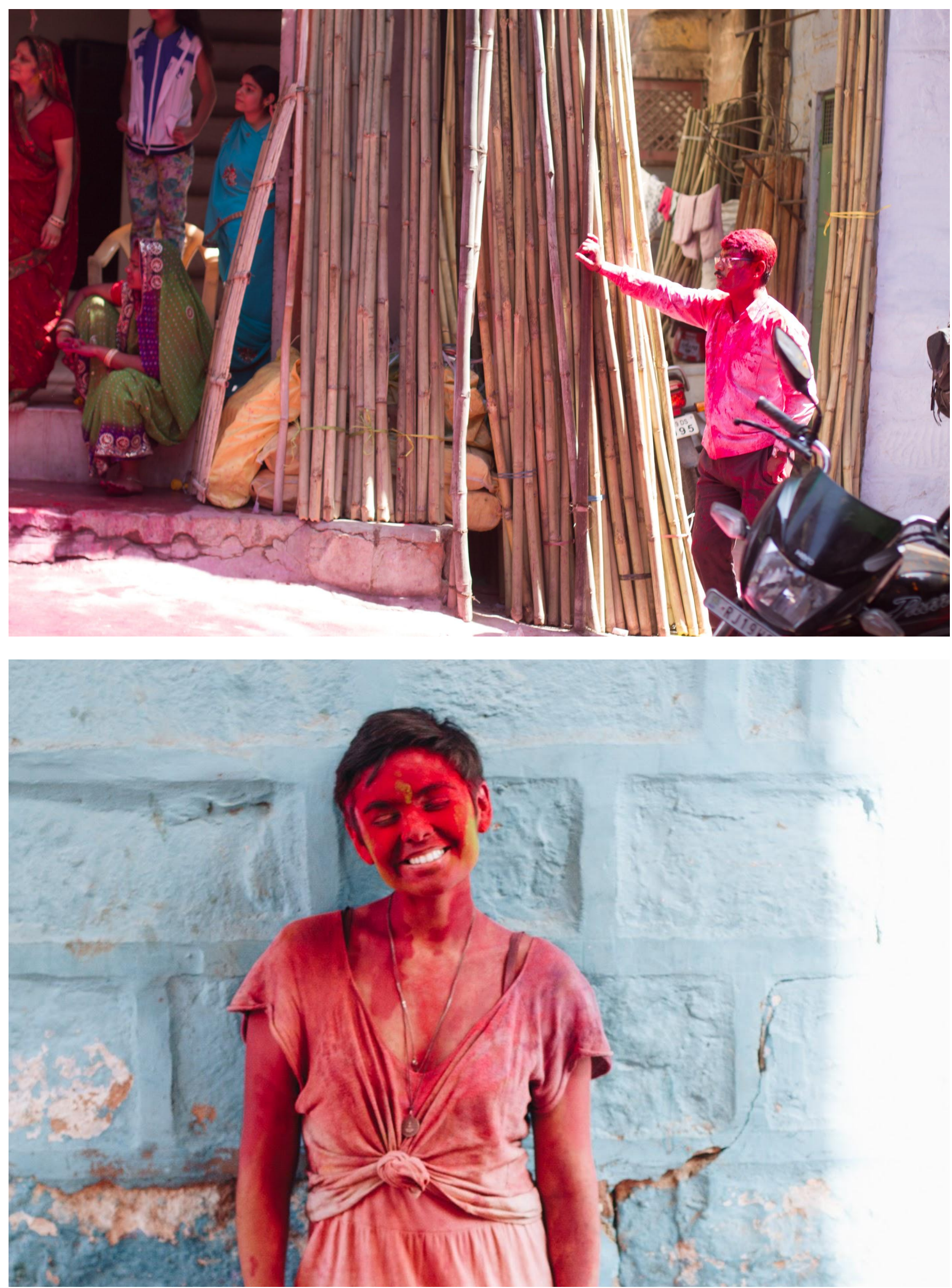


\section{JOSHA}

Journal of Science, Humanities and Arts

\section{About the Author:}

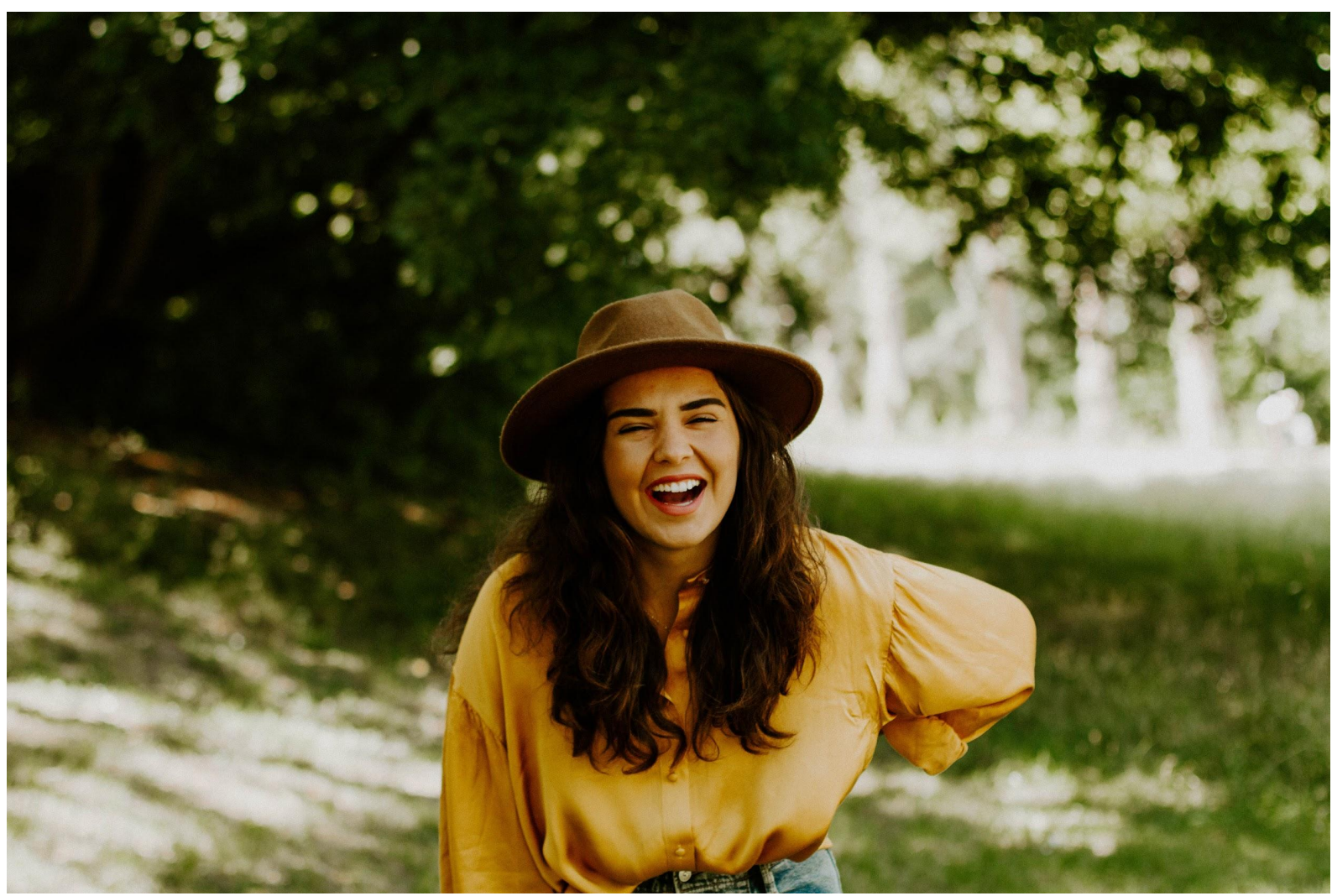

I'm Johanna, a Mexican-American portrait photographer, sometimes-writer, ethnology student, and the heart behind The Together Project currently calling Freiburg, Germany home!

I'm passionate about sharing the kindness, light, and connection that humans have shown me across the globe- which is ultimately the inspiration behind The Together Project.

The Together Project is a series of photo essays inspiring us to see humankind with a sense of curiosity and compassion. The Together Project is here to inspire you to learn something new and meaningful about a culture you may have never known about, creating a sense of understanding and connection towards people you may have not yet come into contact with.

If you'd like to see more of my work, feel welcome to visit my website at http://www.johannapatton.com 